\title{
Characterization of Methylammonium/Ammonium Transport in Mutant Strains of Anabaena variabilis Resistant to Ammonium Analogues
}

\author{
By ANTHONY REGLINSKI, PETER ROWELL, ${ }^{*}$ NIGEL W. KERBY AND \\ WILLIAM D. P. STEWART \\ AFRC Research Group on Cyanobacteria and Department of Biological Sciences, \\ University of Dundee, Dundee DDI $4 H N, U K$
}

(Received 6 September 1988; revised 28 February 1989; accepted 10 March 1989)

\begin{abstract}
A methylamine-resistant mutant strain (4m3) of Anabaena variabilis ATCC 29413 was capable of growth at $\mathrm{pH} 7 \cdot 0$, but not at $\mathrm{pH} 9.0$, in the presence of concentrations of methylamine that totally inhibited growth of the parent strain. Strain $4 \mathrm{~m} 3$ showed a marked reduction, at $\mathrm{pH} 7 \cdot 0$ but not at $\mathrm{pH} \mathrm{9.0,} \mathrm{in} \mathrm{the} \mathrm{initial} \mathrm{rapid} \mathrm{and} \mathrm{slower} \mathrm{second} \mathrm{phases} \mathrm{of} \mathrm{uptake} \mathrm{of}\left[{ }^{14} \mathrm{C}\right]$ methylamine and ammonia, when compared with the parent strain, The rate of inhibition of nitrogenase activity, on adding ammonia at $\mathrm{pH} 7.0$, was lower in strain $4 \mathrm{~m} 3$ than in the parent strain and was attributable to a defect in the $\mathrm{CH}_{3} \mathrm{NH}_{3}^{+} / \mathrm{NH}_{4}^{+}$transport system. Evidence that the second slower phase of $\left[{ }^{14} \mathrm{C}\right]$ methylamine uptake is associated with metabolism via glutamine synthetase (GS) was obtained using mutant strains partially deficient in GS. Unlike these GSdeficient strains, strain $4 \mathrm{~m} 3$ did not liberate ammonia extracellularly unless treated with L-methionine-DL-sulphoximine. Growth of strain $4 \mathrm{~m} 3$ in medium containing $3 \mathrm{~mm}$ methylamine resulted in a restoration of the first phase of $\left[{ }^{14} \mathrm{C}\right]$ methylamine uptake, at $\mathrm{pH} 7 \cdot 0$, but not of ammonia uptake. However, growth in the presence of $3 \mathrm{~mm}$-ammonia did not enhance the uptake of either methylamine or ammonia. Strain $4 \mathrm{~m} 3$ is apparently deficient in the active $\mathrm{CH}_{3} \mathrm{NH}_{3}^{+} / \mathrm{NH}_{4}^{+}$transport system, but has a $\mathrm{CH}_{3} \mathrm{NH}_{3}^{+}$transport system which can be induced by growth in the presence of methylamine.
\end{abstract}

\section{INTRODUCTION}

The existence of $\mathrm{NH}_{4}^{+}$transport systems in free-living $\mathrm{N}_{2}$-fixing organisms is of interest because nitrogenase activity and synthesis are usually inhibited when the organisms are exposed to high concentrations of ammonia (see Murry \& Benemann, 1979; Eady et al., 1982; Stewart $e t$ al., 1985). Most cyanobacteria resemble other micro-organisms in taking up ammonia in preference to other nitrogen sources (Ohmori et al., 1977).

$\mathrm{NH}_{3}$ is a small, uncharged molecule which can pass freely through lipid bilayers by passive diffusion, and a possible mechanism for accumulation of ammonia, at external $\mathrm{pH}$ values higher than the cytoplasmic $\mathrm{pH}$, could involve simple diffusion followed by trapping through protonation, given a membrane permeable to $\mathrm{NH}_{3}$ but impermeable to $\mathrm{NH}_{4}^{+}$[the terms ammonia or methylamine are used, throughout this paper, unless the charged $\left(\mathrm{NH}_{4}^{+}\right.$or $\left.\mathrm{CH}_{3} \mathrm{NH}_{3}^{+}\right)$or uncharged $\left(\mathrm{NH}_{3}\right.$ or $\mathrm{CH}_{3} \mathrm{NH}_{2}$ ) species are meant specifically]. Such a mechanism could not, however, account for the observed accumulation of ammonia against a concentration gradient at external $\mathrm{pH}$ values lower than the cytoplasmic $\mathrm{pH}$.

Methylammonium $\left(\mathrm{CH}_{3} \mathrm{NH}_{3}^{+}\right)$, an analogue of $\mathrm{NH}_{4}^{+}$, has frequently been used as a substrate for studying $\mathrm{NH}_{4}^{+}$transport systems (Alef \& Kleiner, 1982; Boussiba et al., 1984a; Rai et al., 1984; Kerby et al., 1986a; for a review see Kerby et al., 1987a). Recent studies on Anabaena

\footnotetext{
Abbreviations: CCCP, carbonylcyanide- $m$-chlorophenylhydrazone; chl $a$, chlorophyll $a$; GS, glutamine synthetase; MSX, L-methionine-DL-sulphoximine.
} 
variabilis have shown that $\mathrm{CH}_{3} \mathrm{NH}_{3}^{+}$uptake is biphasic, with the first phase representing active (probably $\Delta \psi$-dependent) transport into the cells and the second phase being dependent upon sustained assimilation of methylamine via glutamine synthetase (GS), resulting in $\gamma$-methylglutamine formation (Rai et al., 1984; Kerby et al., 1986a). Inhibition of GS by treatment with L-methionine-DL-sulphoximine (MSX) (Stewart \& Rowell, 1975) has been employed as a means of distinguishing between methylamine transport into cells and its subsequent metabolism via GS (Boussiba et al., 1984a; Kerby et al., 1986a). Thus, there is evidence that MSX has no effect on the rapid phase of methylamine uptake into the cells but inhibits the second slower phase of uptake associated with the formation of $\gamma$-methylglutamine (Boussiba et al., 1984a; Rai et al., 1984; Kerby et al., 1986a). It has been suggested that it is not ammonia per se but a product of its assimilation via GS which regulates nitrogenase synthesis (Stewart \& Rowell, 1975; Ramos et al., 1985; Reich et al., 1986; Helber et al., 1988). However, Singh et al. (1983) and Turpin et al. (1984) have proposed that MSX directly inhibits the $\mathrm{NH}_{4}^{+}$ transport system, and that $\mathrm{NH}_{4}^{+}$per se regulates nitrogenase synthesis. It was further proposed that the two phases of uptake represent two different $\mathrm{NH}_{4}^{+}$transport systems, with the second slower phase being attributed to an MSX-sensitive transport system (Singh et al., 1985).

In this paper we consider the uptake and metabolism of methylamine and ammonia and their effects on nitrogenase activity in a mutant strain of $A$. variabilis resistant to the ammonia analogue methylamine. To our knowledge, this is the first reported characterization of an $\mathrm{NH}_{4}^{+}$ transport mutant of a cyanobacterium, providing new information on $\mathrm{NH}_{4}^{+}$transport.

\section{METHODS}

Organisms and growth conditions. The parent strain (Anabaena variabilis Kütz. ATCC 29413), mutant strains ED81 and ED92 (Polukhina et al., 1982) and the methylamine-resistant mutant strain $4 \mathrm{~m} 3$ were grown under air in batch culture in BG-11 0 medium (which is free of combined nitrogen) (Rippka et al., 1979) at $25^{\circ} \mathrm{C}$ and in continuous light at a photon fluence rate of $15 \mu \mathrm{mol} \mathrm{m} \mathrm{m}^{-2} \mathrm{~s}^{-1}$.

Mutagenesis and mutant selection. This was a modification of the method described previously (Kerby et al., $1987 b$ ). A. variabilis cells were harvested by centrifugation from exponential-phase cultures and were resuspended in $10 \mathrm{~mm}-\mathrm{HEPES} / \mathrm{NaOH}$ ( $\mathrm{pH} 7 \cdot 0$ ). Cultures were sonicated in a cleaning bath (Cole Parmer, Illinois) until filaments were reduced to an average length of two cells. The cells were washed twice in $10 \mathrm{mM}-\mathrm{HEPES} / \mathrm{NaOH}$ (pH 7.0) and $N$-methyl- $N^{\prime}$-nitro- $N$-nitrosoguanidine was added to a concentration of $250 \mu \mathrm{g} \mathrm{ml}^{-1}$. The suspension was incubated for $4 \mathrm{~h}$ at $30^{\circ} \mathrm{C}$ in the light $\left(15 \mu \mathrm{mol} \mathrm{m} \mathrm{m}^{-2} \mathrm{~s}^{-1}\right)$ with shaking. The treatment was terminated by washing the cells three times with BG-11 $1_{0}$ and resuspending in BG-11 $1_{0}$; it resulted in a $1 \%$ survival of cells.

In order to isolate mutant strains resistant to methylamine, mutagenized cells were grown at $30{ }^{\circ} \mathrm{C}$ at a photon fiuence rate of $15 \mu \mathrm{mol} \mathrm{m}{ }^{-2} \mathrm{~s}^{-1}$ for several generations, sonicated as above, and then plated onto BG-11 $1_{0}$ plates solidified with $1 \%(\mathrm{w} / \mathrm{v})$ agar containing $10 \mathrm{~mm}-\mathrm{HEPES} / \mathrm{NaOH}(\mathrm{pH} 7 \cdot 0)$ and $1 \mathrm{~mm}$-methylamine. Colonies resistant to methylamine were picked after incubation in the light $\left(15 \mu \mathrm{mol} \mathrm{m}^{-2} \mathrm{~s}^{-1}\right)$ at $30^{\circ} \mathrm{C}$ to allow colony development and restreaked on selective medium a further five times prior to growth in liquid BG-11 $1_{0}$ containing $10 \mathrm{~mm}-\mathrm{HEPES} / \mathrm{NaOH}(\mathrm{pH} 7 \cdot 0$ ) and $1 \mathrm{~mm}$-methylamine.

Chlorophyll a determinations. Chlorophyll was extracted in methanol in the dark at $4{ }^{\circ} \mathrm{C}$. Absorbance was measured at $663 \mathrm{~nm}$ and the chlorophyll $a$ (chl $a$ ) concentration calculated according to Mackinney (1941).

$\left[{ }^{14} \mathrm{C}\right]$ Methylamine uptake. The cyanobacteria were harvested during exponential growth, washed and resuspended in either $10 \mathrm{~mm}-\mathrm{HEPES} / \mathrm{NaOH}(\mathrm{pH} \mathrm{7.0)}$ or $10 \mathrm{~mm}$-Tricine/ $\mathrm{NaOH}(\mathrm{pH} \mathrm{9.0)}$ and equilibrated for $30 \mathrm{~min}$ at a photon fluence rate of $75 \mu \mathrm{mol} \mathrm{m}-2 \mathrm{~s}^{-1}$ at $25^{\circ} \mathrm{C} .{ }^{14} \mathrm{C}$-labelled methylamine was then added to the cell suspension (approximately $10 \mu \mathrm{g} \mathrm{chl} \mathrm{a} \mathrm{ml}^{-1}$ ) to a final concentration of $30 \mu \mathrm{M}$ (specific activity $10 \mathrm{kBq} \mathrm{ml}^{-1}$ ). After periods of incubation, the cells were removed from their bathing medium by microcentrifugation through Dow Corning 550 silicon oil/dinonylphthalate $(40: 60, \mathrm{v} / \mathrm{v})$ into perchloric acid in water $(15 \%, \mathrm{v} / \mathrm{v})$ (Rai et al., 1984). Samples of the perchloric acid fraction were withdrawn for estimation of ${ }^{14} \mathrm{C}$ incorporation by liquid scintillation counting using a toluene-based scintillant and a Packard $300 \mathrm{CD}$ scintillation counter. As a result of experimental difficulties in quantifying non-specific binding and/or carry-over of bathing medium, no correction was routinely applied to the ${ }^{14} \mathrm{C}$ incorporated.

Ammonia uptake. The cyanobacteria were harvested during exponential growth, washed and resuspended, to a concentration of approximately $10 \mu \mathrm{g} \mathrm{chl} a \mathrm{ml}^{-1}$, in $50 \mathrm{ml}$ of either $10 \mathrm{mM}-\mathrm{HEPES} / \mathrm{NaOH}(\mathrm{pH} 7.0)$ or $10 \mathrm{mM}^{-}$ Tricine/ $\mathrm{NaOH}\left(\mathrm{pH} \mathrm{9.0)}\right.$ ) and equilibrated for $30 \mathrm{~min}$ at a photon fluence rate of $75 \mu \mathrm{mol} \mathrm{m}^{-2} \mathrm{~s}^{-1}$ at $25^{\circ} \mathrm{C}$. The uptake of ammonia was initiated by addition of a known concentration of $\mathrm{NH}_{4} \mathrm{Cl}$ to the cell suspension. After periods of incubation the cells were removed from their bathing medium by centrifugation. $\mathrm{NaOH}$ (final concentration $0.1 \mathrm{M}$ ) was added to the bathing medium to convert $\mathrm{NH}_{4}^{+}$to $\mathrm{NH}_{3}\left(\mathrm{p} K_{\mathrm{a}}=9 \cdot 25\right)$ and $\mathrm{NH}_{3}$ 
concentration was determined using an $\mathrm{NH}_{3}$ gas sensing electrode (Russell $\mathrm{pH}$, Auchtermuchty, Scotland). The electrode was calibrated using a range of $\mathrm{NH}_{4} \mathrm{Cl}$ concentrations.

Ammonia liberation. Ammonia in the growth medium was determined using the method of Solorzano (1969), after removal of cells by centrifugation.

Methylamine and ammonia metabolism. Measurement of methylamine and ammonia incorporation into amino acids was carried out by incubating cells $(200 \mu \mathrm{g} \mathrm{chl} a)$ in $10 \mathrm{mM}-\mathrm{HEPES} / \mathrm{NaOH}(\mathrm{pH} 7.0)$ containing a known concentration of either methylamine or ammonia at $25^{\circ} \mathrm{C}$ and a photon fluence rate of $75 \mu \mathrm{mol} \mathrm{m}^{-2} \mathrm{~s}^{-1}$. The cells were harvested and amino acid extraction and analysis performed as before (Kerby et al., 1986a). For calculation of amino acid pool concentrations, the intracellular volume was determined by the method of Reed et al. (1987).

Glutamine synthetase (GS) activity. Cell-free extracts were prepared by sonication in $50 \mathrm{mM}$-Tris/ $\mathrm{HCl}(\mathrm{pH} 7.5)$, $2 \mathrm{mM}-\mathrm{Na}_{2}$ EDTA, $3 \mathrm{~mm}$-dithiothreitol and $5 \mathrm{mM}-\mathrm{MgCl}_{2}$ followed by centrifugation at $10000 \mathrm{~g}$. GS $\mathrm{Mg}^{2+}$ dependent biosynthetic activity was assayed as described previously (Kerby et al., 1986a).

Nitrogenase activity. This was determined using the acetylene reduction assay (Stewart et al., 1967).

Protein determination. Protein concentrations of cell-free extracts were determined by the method of Bradford (1976).

Chemicals. $\left[{ }^{14} \mathrm{C}\right]$ Methylamine hydrochloride was obtained from Amersham. All other chemicals were obtained from Sigma or BDH.

\section{RESULTS}

Methylamine-resistant mutant strains of Anabaena variabilis were obtained by selecting for growth at $\mathrm{pH} 7.0$ in the presence of $1 \mathrm{mM}$-methylamine, a concentration which completely inhibited growth of the parent strain. The kinetics of uptake of ${ }^{14} \mathrm{C}$-labelled methylamine were determined for each of 10 methylamine-resistant strains, in order to identify any strains that might be deficient in $\mathrm{CH}_{3} \mathrm{NH}_{3}^{+}$transport and/or metabolism (Rai et al., 1984; Kerby et al., $1986 a$ ). Six of the strains tested showed kinetics of $\left[{ }^{14} \mathrm{C}\right]$ methylamine uptake, at an external $\mathrm{pH}$ of $7 \cdot 0$, which were similar to those of the parent strain or even showed enhanced uptake (data not shown), when compared with the parent strain. Four strains showed a reduced $\left[{ }^{14} \mathrm{C}\right]$ methylamine uptake at $\mathrm{pH} 7 \cdot 0$, and one of these $(4 \mathrm{~m} 3)$, which showed the most marked reduction, was further characterized with respect to the uptake and assimilation of methylamine and ammonia.

The kinetics of growth of the parent strain and strain $4 \mathrm{~m} 3$ at pH 7.0 were similar in $\mathrm{N}$-free medium or in medium containing $3 \mathrm{~mm}$-ammonia (doubling time 110-135 h), although strain $4 \mathrm{~m} 3$ showed a longer lag phase in the presence of ammonia. The growth of strain $4 \mathrm{~m} 3$ (doubling time $135 \mathrm{~h}$ ) was not inhibited in medium containing 3 mm-methylamine at $\mathrm{pH} 7.0$ whereas growth of the parent strain was totally inhibited. Neither the parent strain nor strain $4 \mathrm{~m} 3$ was capable of growth in medium containing $1 \mathrm{mM}$-methylamine at $\mathrm{pH} 9 \cdot \mathbf{0}$.

\section{Kinetics of methylamine uptake by strain $4 m 3$}

As previously demonstrated (Rai et al., 1984; Kerby et al., 1986a), the parent strain showed a typical biphasic uptake of $\left[{ }^{14} \mathrm{C}\right]$ methylamine at external $\mathrm{pH}$ values of $7 \cdot 0$ and 9.0 (Fig. 1). At pH 7.0 (Fig. 1a), strain $4 \mathrm{~m} 3$, grown in $\mathrm{N}$-free medium, showed a reduced first phase of methylamine uptake and a slower second phase of uptake than the parent strain, whereas at pH 9.0 (Fig. $1 \mathrm{~b}$ ), the kinetics of uptake were similar to those of the parent strain. The reduced first phase of uptake at $\mathrm{pH} 7.0$ indicates a deficiency in $\mathrm{CH}_{3} \mathrm{NH}_{3}^{+}$transport which is not apparent at $\mathrm{pH} 9 \cdot 0$, where methylamine can accumulate internally by passive diffusion of $\mathrm{CH}_{3} \mathrm{NH}_{2}$ followed by ion trapping in response to the $\mathrm{pH}$ gradient (lower inside, assuming a cytoplasmic $\mathrm{pH}$ of approximately $7 \cdot 5$ : see Hawkesford et al., 1983). Since the rate of uptake during the first phase is too rapid for accurate measurement, only the extent of uptake in this phase was determined.

The rates of the second phase of methylamine uptake (Fig. 1) were 20 and $23 \mathrm{pmol} \mathrm{min}^{-1}$ ( $\mu \mathrm{g}$ $\operatorname{chl} a)^{-1}$ at $\mathrm{pH} 7.0$ and $\mathrm{pH} 9.0$, respectively, for the parent strain, and 4 and $19 \mathrm{pmol} \mathrm{min}^{-1}(\mu \mathrm{g}$ $\operatorname{chl} a)^{-1}$ at $\mathrm{pH} 7 \cdot 0$ and $\mathrm{pH} 9 \cdot 0$, respectively, for strain $4 \mathrm{~m} 3$. When strain $4 \mathrm{~m} 3$ was grown in medium containing $3 \mathrm{~mm}$-methylamine, the first phase of uptake of methylamine at $\mathrm{pH} 7.0$ (Fig. 1a) was increased to a level identical to that of the parent strain grown in $\mathrm{N}$-free medium, 


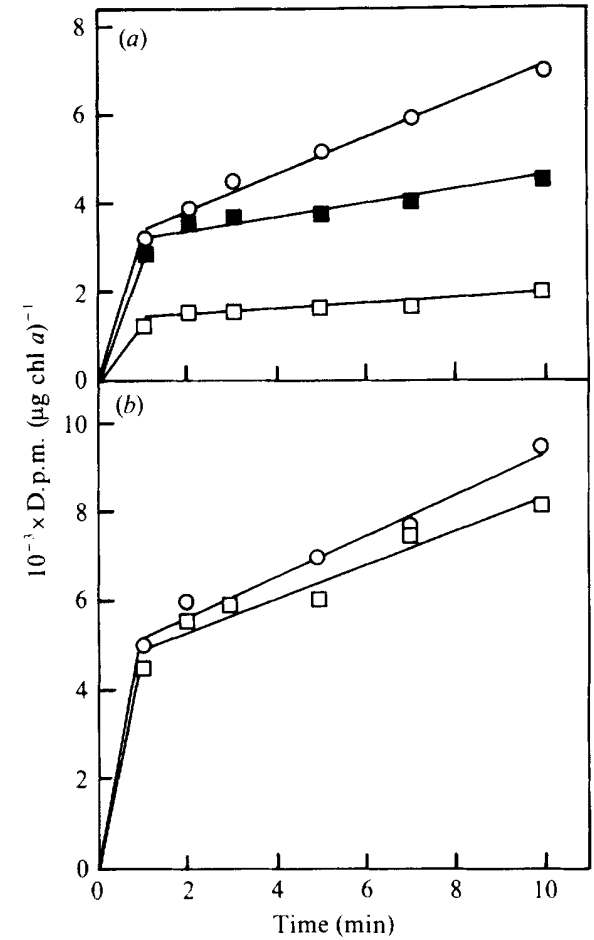

Fig. 1

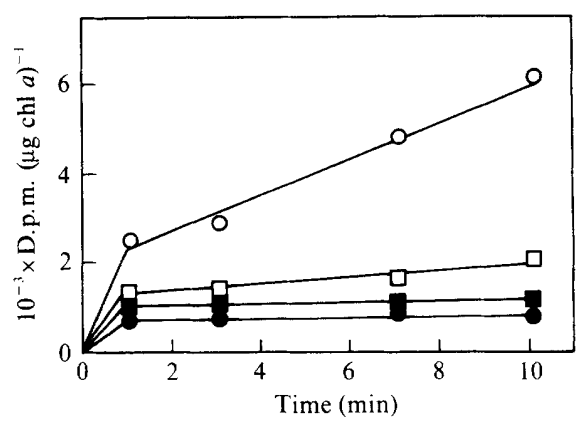

Fig. 2

Fig. 1. Methylamine uptake at $\mathrm{pH} 7 \cdot 0(a)$ and $\mathrm{pH} 9 \cdot 0(b)$ by the parent strain $(O)$ and mutant strain $4 \mathrm{~m} 3$

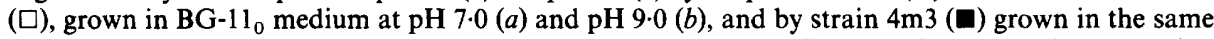
medium containing $3 \mathrm{~mm}$-methylamine at $\mathrm{pH} 7 \cdot 0$. Media were buffered at the appropriate $\mathrm{pH}$ using $10 \mathrm{~mm}-\mathrm{HEPES} / \mathrm{NaOH}\left(\mathrm{pH} 7 \cdot 0\right.$ ) or $10 \mathrm{~mm}-\mathrm{Tricine} / \mathrm{NaOH}\left(\mathrm{pH} \mathrm{9.0)} .{ }^{14} \mathrm{CH}_{3} \mathrm{NH}_{3} \mathrm{Cl}\right.$ was added to give a concentration of $30 \mu \mathrm{M}$ at zero time. Lines were fitted to data points from 1 to $10 \mathrm{~min}$ by linear regression. In this and other figures, the results are means of at least three replicates, with standard errors being less than $\pm 10 \%$ of the mean.

Fig. 2. Effects of the uncoupler CCCP on methylamine uptake at pH 7.0 by the parent strain $(O, \bullet)$ and mutant strain $4 \mathrm{~m} 3(\square, \square)$ grown in BG-11 $1_{0}$ medium at pH 7.0. Prior to adding ${ }^{14} \mathrm{CH}_{3} \mathrm{NH}_{3} \mathrm{Cl}$ (to 30 $\mu \mathrm{M})$ at zero time, cell suspensions in $10 \mathrm{mM}-\mathrm{HEPES} / \mathrm{NaOH}(\mathrm{pH} 7 \cdot 0)$ were incubated either in the light at a photon fluence rate of $75 \mu \mathrm{mol} \mathrm{m}^{-2} \mathrm{~s}^{-1}$ in the absence of $\operatorname{CCCP}(O, \square)$ or in the dark with $100 \mu \mathrm{M}$ $\operatorname{CCCP}(\bullet, \mathbf{a})$ for $3 \mathrm{~h}$.

although growth in the presence of $3 \mathrm{~mm}$-ammonia (data not shown) did not have this effect. These findings indicate the presence of a methylamine-induced $\mathrm{CH}_{3} \mathrm{NH}_{3}^{+}$transport system. The rate of the second phase of uptake $\left[8 \mathrm{pmol} \mathrm{min}^{-1}(\mu \mathrm{g} \mathrm{chl} \mathrm{a})^{-1}\right]$ by strain $4 \mathrm{~m} 3$ grown in the presence of methylamine was lower than that for the parent strain. Since the second phase of uptake of methylamine is considered to be dependent on the metabolism of methylamine via GS, the data indicate a lower rate of methylamine metabolism in strain $4 \mathrm{~m} 3$ than in the parent strain. GS biosynthetic activities in cell-free extracts of the parent strain and strain $4 \mathrm{~m} 3$ were similar [ 73 and $63 \mathrm{nmol}$ product formed $\mathrm{min}^{-1}$ (mg protein) ${ }^{-1}$, respectively]. This suggests that the reduced second phase of methylamine uptake is not due to a reduction in GS activity under substrate-saturating conditions. As we have previously shown (Kerby et al., 1986b), addition of 3 mM-ammonia to $A$. variabilis at $\mathrm{pH} 7.0$ caused a rapid efflux of radioactivity and prevented further $\left[{ }^{14} \mathrm{C}\right]$ methylamine uptake. In both the parent strain and the mutant strain, the magnitude of the efflux of radioactivity was similar to that of the first phase of uptake of methylamine (data not shown) and probably represents displacement of the internal free pool of methylamine together with some non-specifically bound $\mathrm{CH}_{3} \mathrm{NH}_{3}^{+}$. To check the extent to 
Table 1. Effects of ammonia and methylamine on amino acid pools of the parent strain and mutant strain $4 m 3$

\begin{abstract}
Free pools of glutamate, glutamine and $\gamma$-methylglutamine (MeGln) were determined before (control) and after adding $50 \mu \mathrm{M}-\mathrm{NH}_{4} \mathrm{Cl}\left(20 \mathrm{~min}\right.$ incubation) or $30 \mu \mathrm{M}-\mathrm{CH}_{3} \mathrm{NH}_{3} \mathrm{Cl}(30 \mathrm{~min}$ incubation) at $\mathrm{pH} 7 \cdot 0$. Cells grown in batch culture in BG-1 $1_{0}$ medium were harvested by centrifugation, resuspended in $10 \mathrm{~mm}$ HEPES/ $\mathrm{NaOH}\left(\mathrm{pH} \mathrm{7.0)}\right.$ ) and allowed to equilibrate for $30 \mathrm{~min}$ at $25^{\circ} \mathrm{C}$ and a photon fluence rate of $75 \mu \mathrm{mol} \mathrm{m}{ }^{-2} \mathrm{~s}^{-2}$, prior to adding $\mathrm{NH}_{4} \mathrm{Cl}$ or $\mathrm{CH}_{3} \mathrm{NH}_{3} \mathrm{Cl}$. ND, not detectable.
\end{abstract}

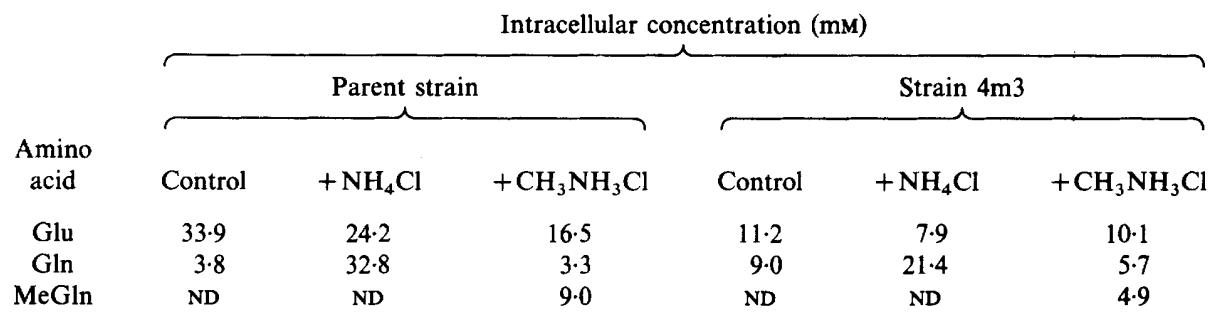

which the uptake of $\left[{ }^{14} \mathrm{C}\right]$ methylamine was due to non-specific binding to the cells and/or carryover of bathing medium, uptake was examined (Fig. 2) at $\mathrm{pH} 7.0$ in the dark in cells pretreated for $3 \mathrm{~h}$ with the uncoupler carbonylcyanide- $m$-chlorophenylhydrazone (CCCP) at a concentration of $100 \mu \mathrm{M}$ (see Hawkesford et al., 1983). Under these conditions, where both the transport and metabolism of methylamine should be inhibited, the first phase of uptake of methylamine by the parent strain was reduced by about $75 \%$. The residual uptake of methylamine presumably represents non-specific binding to the cells. In strain $4 \mathrm{~m} 3$, grown in the absence of methylamine, pretreatment with CCCP resulted in only a slight reduction (approximately $30 \%$ ) in the first phase of uptake of methylamine, indicating that most of the apparent methylamine uptake at $\mathrm{pH} \mathrm{7.0} \mathrm{does} \mathrm{not} \mathrm{represent} \mathrm{the} \mathrm{accumulation} \mathrm{of} \mathrm{an} \mathrm{endogenous} \mathrm{free} \mathrm{pool} \mathrm{of} \mathrm{methylamine,} \mathrm{but}$ perhaps results from the non-specific binding of $\mathrm{CH}_{3} \mathrm{NH}_{3}^{+}$to the cells.

\title{
Relationship between methylamine uptake and the synthesis of $\gamma$-methylglutamine
}

It has previously been shown that the pretreatment of $A$. variabilis with MSX, to wholly or partially inactivate GS, results in a corresponding reduction in the second phase of methylamine uptake and also inhibits the intracellular accumulation of $\gamma$-methylglutamine (Rai et al., 1984; Kerby et al., 1986a). To further examine the relationship between the second phase of uptake of methylamine and GS activity, $\left[{ }^{14} \mathrm{C}\right]$ methylamine uptake and $\gamma$-methylglutamine accumulation over a $30 \mathrm{~min}$ period were compared. In strain $4 \mathrm{~m} 3$ the rate of $\left[{ }^{14} \mathrm{C}\right]$ methylamine uptake increased to $9 \mathrm{pmol} \mathrm{min}^{-1}(\mu \mathrm{g} \mathrm{chl} a)^{-1}$ after $30 \mathrm{~min}$, resulting in a higher mean rate of uptake over a 30 min period than over the $10 \mathrm{~min}$ period shown in Fig. 1, whereas in the parent strain,

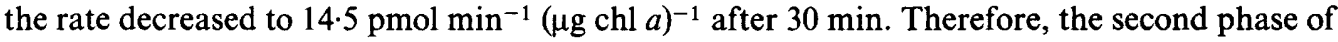
uptake corresponded to a total uptake between 1 and 30 min of 0.48 and $0.24 \mathrm{nmol}$ methylamine $(\mu \mathrm{g} \mathrm{chl} a)^{-1}$ for the parent strain and strain $4 \mathrm{~m} 3$, respectively. The free pools of $\gamma$-methylglutamine (Table 1), $30 \mathrm{~min}$ after adding $30 \mu \mathrm{M}$-methylamine, were 0.49 and $0.27 \mathrm{nmol}$ $(\mu \mathrm{g} \mathrm{chl} a)^{-1}$ for the parent strain and strain $4 \mathrm{~m} 3$, respectively. Thus, the amount of methylamine taken up corresponds with the amount of $\gamma$-methylglutamine formed, confirming that the second phase of uptake depends on metabolism via GS and that $\gamma$-methylglutamine is not further metabolized, as we have previously shown for the parent strain (Rai et al., 1984; Kerby et al., $1986 a$ ). Strain $4 \mathrm{~m} 3$ accumulated $\gamma$-methylglutamine intracellularly [12 $\mathrm{nmol}(\mu \mathrm{g} \mathrm{chl} a)^{-1}$; (approximately $220 \mathrm{mM}$ in chemostat cultures at pH 7.0 with $3 \mathrm{mM}$-methylamine in the growth medium)], although no significant further metabolism was detected.

\section{Kinetics of methylamine uptake by mutant strains deficient in $G S$}

Strains ED81 and ED92 are mutant strains of $A$. variabilis resistant to ethylenediamine (1,2diaminoethane), which have reduced GS biosynthetic activity and which liberate ammonia extracellularly (Kerby ${ }^{2}$ et al., 1986 b). As Fig. 3 shows, the first phases of $\left[{ }^{14} \mathrm{C}\right]$ methylamine 


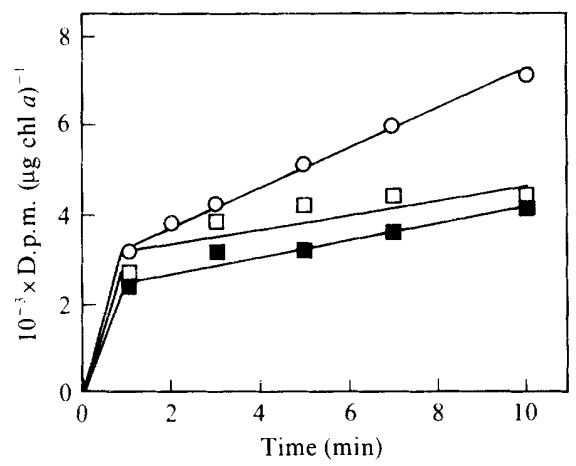

Fig. 3. Methylamine uptake at $\mathrm{pH} 7 \cdot 0$ by the parent strain $(O)$ and mutant strains ED92 ( $\square$ ) and ED81 (E) grown in BG-11 $1_{0}$ medium at $\mathrm{pH} 7 \cdot 0$. For other experimental details, see legend to Fig. 2.

uptake by ED81 and ED92 at pH 7.0 were similar to that of the parent strain, whereas the second phases of uptake were reduced by $60 \%$ and $63 \%$ in ED 81 and ED92, respectively. Thus ED81, which has a catalytically deficient GS, and ED92, which synthesizes reduced levels of GS protein and mRNA (Hien et al., 1988), do not show a deficiency in the $\mathrm{CH}_{3} \mathrm{NH}_{3}^{+} / \mathrm{NH}_{4}^{+}$transport system. The fact that both of these mutant strains have a reduced second phase of uptake of methylamine is again consistent with its dependence on an active GS.

\section{Kinetics of ammonia uptake by the parent strain and strain $4 m 3$}

Ammonia uptake at $\mathrm{pH} 7 \cdot 0$ and $\mathrm{pH} 9 \cdot 0$, at external concentrations of $50 \mu \mathrm{M}$-ammonia (Fig. 4) and $1 \mathrm{~mm}$-ammonia (Fig. 5), showed a rapid initial uptake followed by a slower linear uptake. Ammonia uptake, at all time points measured, clearly represents both transport and the subsequent assimilation (Rowell et al., 1977). The slower linear rate of uptake appears to be dependent on the rate of assimilation via GS and not on the rate of transport. At $\mathrm{pH} 9 \cdot 0$, where ammonia uptake may occur by diffusion of $\mathrm{NH}_{3}$, as described above for methylamine, both strains showed similar kinetics of ammonia uptake, with a larger initial uptake occurring at $\mathrm{pH} 9.0$ than at $\mathrm{pH} 7.0$. At $\mathrm{pH} \mathrm{7.0} \mathrm{ammonia} \mathrm{uptake} \mathrm{was} \mathrm{markedly} \mathrm{reduced} \mathrm{in} \mathrm{the} \mathrm{mutant} \mathrm{strain}$ grown in $\mathrm{N}$-free medium (Figs 4 and 5) or in the presence of methylamine (data not shown), indicating that the $\mathrm{NH}_{4}^{+}$transport system is absent or reduced and confirming the above findings for $\mathrm{CH}_{3} \mathrm{NH}_{3}^{+}$transport.

At an external concentration of $1 \mathrm{mM}$-ammonia the initial uptake was greater than at $50 \mu \mathrm{M}$ ammonia. In cells pretreated with $100 \mu \mathrm{M}$-CCCP for $3 \mathrm{~h}$ the ammonia uptake over this initial 5 min period at $\mathrm{pH} 7.0$ was reduced by $76 \%$ in the parent strain and by $34 \%$ in strain $4 \mathrm{~m} 3$, and there was no further uptake (data not shown). The residual uptake of ammonia, in the presence of CCCP, may be attributed to non-specific binding of $\mathrm{NH}_{4}^{+}$to the cells.

The rates of the linear phase of ammonia uptake (assimilation), at an external concentration of $50 \mu \mathrm{M}$-ammonia, were 98 and $90 \mathrm{pmol} \mathrm{min}^{-1}(\mu \mathrm{g} \mathrm{chl} a)^{-1}$ at $\mathrm{pH} 7 \cdot 0$ and $\mathrm{pH} \mathrm{9.0}$, respectively, for the parent strain and 21 and $65 \mathrm{pmol} \mathrm{min}^{-1}(\mu \mathrm{g} \mathrm{chl} a)^{-1}$ at $\mathrm{pH} 7 \cdot 0$ and $\mathrm{pH} \mathrm{9.0,} \mathrm{respectively,}$ for the mutant strain. At an external concentration of $1 \mathrm{~mm}$-ammonia the rates were 62 and $54 \mathrm{pmol} \mathrm{min}^{-1}(\mu \mathrm{g} \mathrm{chl} a)^{-1}$ at $\mathrm{pH} 7.0$ and $\mathrm{pH} \mathrm{9.0,} \mathrm{respectively,} \mathrm{for} \mathrm{the} \mathrm{parent} \mathrm{strain} \mathrm{and} 17$ and $60 \mathrm{pmol} \mathrm{min}^{-1}(\mu \mathrm{g} \mathrm{chl} a)^{-1}$ at $\mathrm{pH} 7.0$ and $\mathrm{pH} 9.0$, respectively, for the mutant strain. Thus ammonia assimilation occurs at similar rates at external $\mathrm{pH}$ values of 7.0 and 9.0 and at external ammonia concentrations of $50 \mu \mathrm{M}$ and $1 \mathrm{mM}$, except in the case of strain $4 \mathrm{~m} 3$, where the rate of assimilation at $\mathrm{pH} 7.0$ was markedly lower. The rates of ammonia assimilation are well within the range of extractable GS activities [an ammonia assimilation rate of $60 \mathrm{pmol} \mathrm{min}^{-1}(\mu \mathrm{g} \mathrm{chl}$

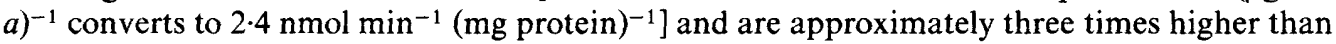
the corresponding rates of methylamine assimilation, which may be related to the fact that GS of A. variabilis has a higher $K_{\mathrm{m}}$ for methylamine than for ammonia (Kerby et al., 1987a). 


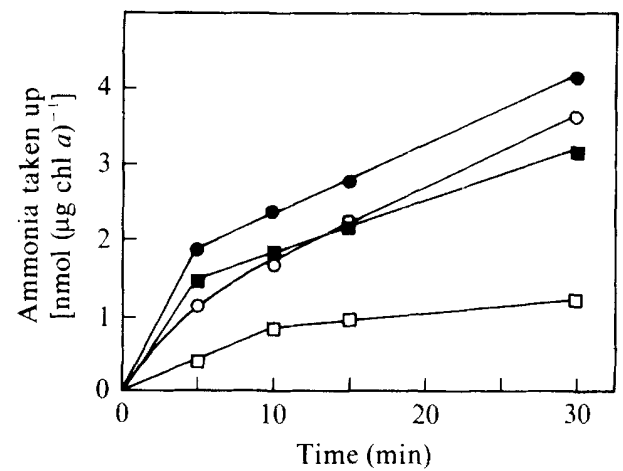

Fig. 4

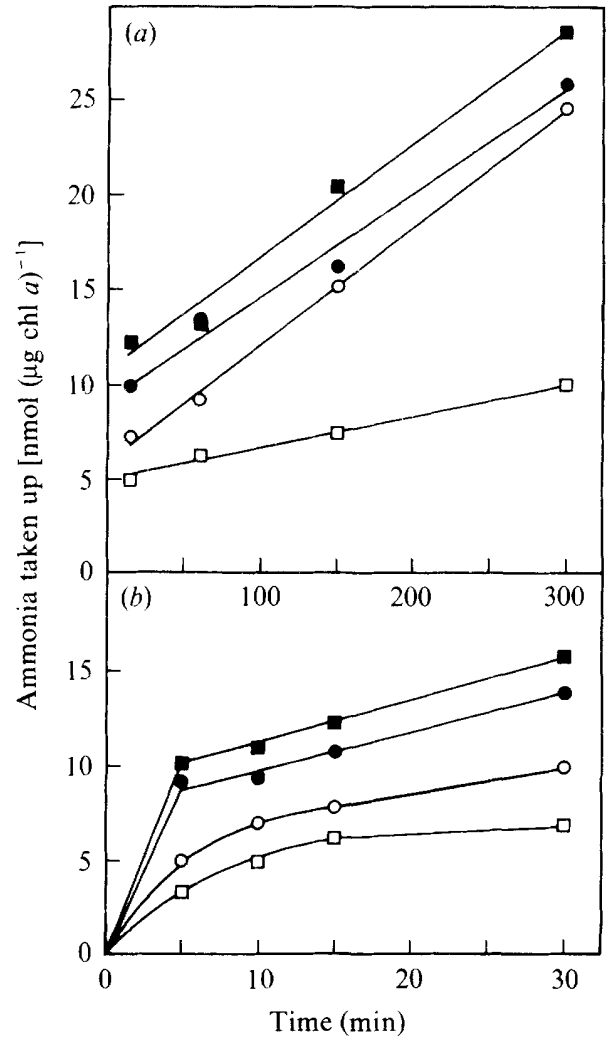

Fig. 5

Fig. 4. Ammonia uptake at $\mathrm{pH} 7 \cdot 0(\mathrm{O}, \square)$ and $\mathrm{pH} 9 \cdot 0(\bullet, \square)$ by the parent strain $(O, \bullet)$, and mutant strain $4 \mathrm{~m} 3(\square, \square)$ suspended in $10 \mathrm{~mm}-\mathrm{HEPES} / \mathrm{NaOH}(\mathrm{pH} 7 \cdot 0)$ or $10 \mathrm{~mm}$-Tricine/ $\mathrm{NaOH}(\mathrm{pH} 9 \cdot 0)$. $\mathrm{NH}_{4} \mathrm{Cl}$ was added, to a concentration of $50 \mu \mathrm{M}$ at zero time, and the disappearance of ammonia from the medium was measured using an $\mathrm{NH}_{3}$-specific electrode.

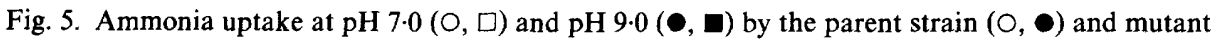
strain $4 \mathrm{~m} 3(\square, \boldsymbol{U})$, over a $5 \mathrm{~h}$ period $(a)$ or a $30 \mathrm{~min}$ period $(b)$. Experimental details are as given in the legend to Fig. 4, except that $\mathrm{NH}_{4} \mathrm{Cl}$ was added to a concentration of $1 \mathrm{mM}$ at zero time.

\section{Effects of ammonia and methylamine on nitrogenase activity}

Strain $4 \mathrm{~m} 3$ had an identical heterocyst frequency $(5.7 \%$ of total cells) and nitrogenase activity [5.6 nmol $\mathrm{C}_{2} \mathrm{H}_{2}$ reduced $\left.\mathrm{h}^{-1}(\mu \mathrm{g} \mathrm{chl} a)^{-1}\right]$ to the parent strain when grown in $\mathrm{N}$-free medium, although the heterocyst frequency and nitrogenase activity were slightly lower $[4.7 \%$ and $5 \cdot 1$ nmol $\mathrm{C}_{2} \mathrm{H}_{2}$ reduced $\mathrm{h}^{-1}(\mu \mathrm{g} \mathrm{chl} a)^{-1}$, respectively] for strain $4 \mathrm{~m} 3$ grown at $\mathrm{pH} 7.0$ in medium containing $3 \mathrm{~mm}$-methylamine, which inhibits growth of the parent strain. However, the addition of ammonia or methylamine affected the nitrogenase activities of the parent strain and strain $4 \mathrm{~m} 3$ differently. On adding $3 \mathrm{~mm}$-ammonia to $\mathrm{N}_{2}$-fixing cultures at $\mathrm{pH} 7 \cdot 0$ (Fig. $6 a$ ), the inhibition of nitrogenase activity was more rapid in the parent strain than in strain $4 \mathrm{~m} 3$, whereas at $\mathrm{pH} 9 \cdot 0$, nitrogenase activities decreased at similar rates in both strains. Addition of ammonia at a lower concentration $(50 \mu \mathrm{M})$ at $\mathrm{pH} 7.0$ (Fig. 7) similarly resulted in a decrease in nitrogenase activity, although when the ammonia concentration fell below approximately $20 \mu \mathrm{M}$, nitrogenase activity recovered. On adding $3 \mathrm{mM}$-methylamine at $\mathrm{pH} 7.0$ (Fig. $6 \mathrm{~b}$ ) there was an initial rapid decrease followed by a recovery of nitrogenase activity in the parent strain whereas that of strain $4 \mathrm{~m} 3$ was virtually unaffected. At $\mathrm{pH} 9 \cdot 0$ methylamine addition, which inhibited growth of both strains, resulted in a more rapid decrease in nitrogenase activity in the parent strain than in strain $4 \mathrm{~m} 3$.

It should be noted that, in contrast with the effects of ammonia and methylamine, addition of nitrate to $\mathrm{N}_{2}$-fixing cultures at $\mathrm{pH} 7.0$ resulted in a greater inhibition of nitrogenase activity in strain $4 \mathrm{~m} 3$ than in the parent strain (Table 2). 


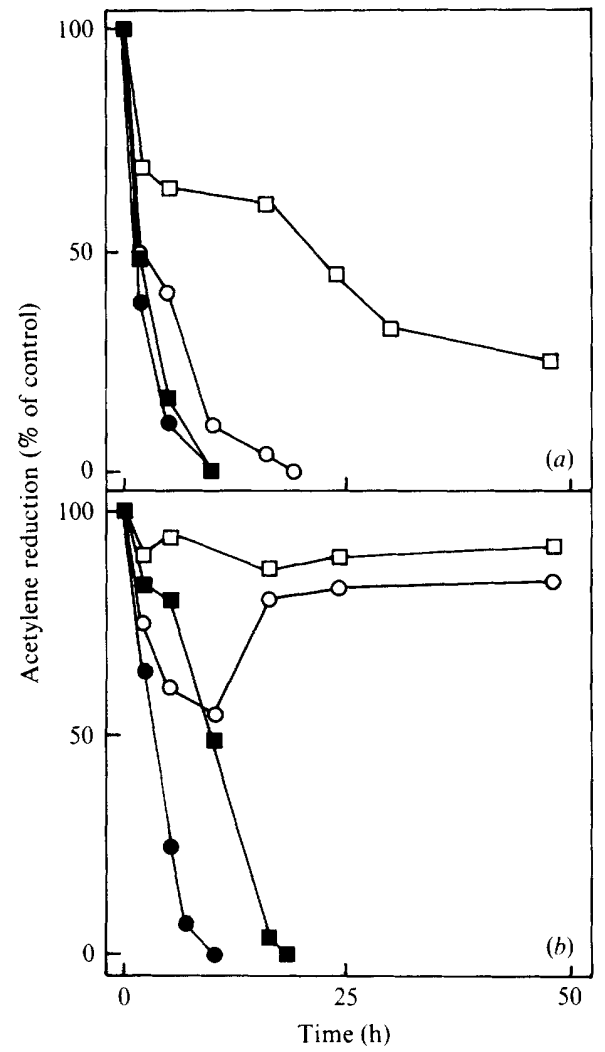

Fig. 6

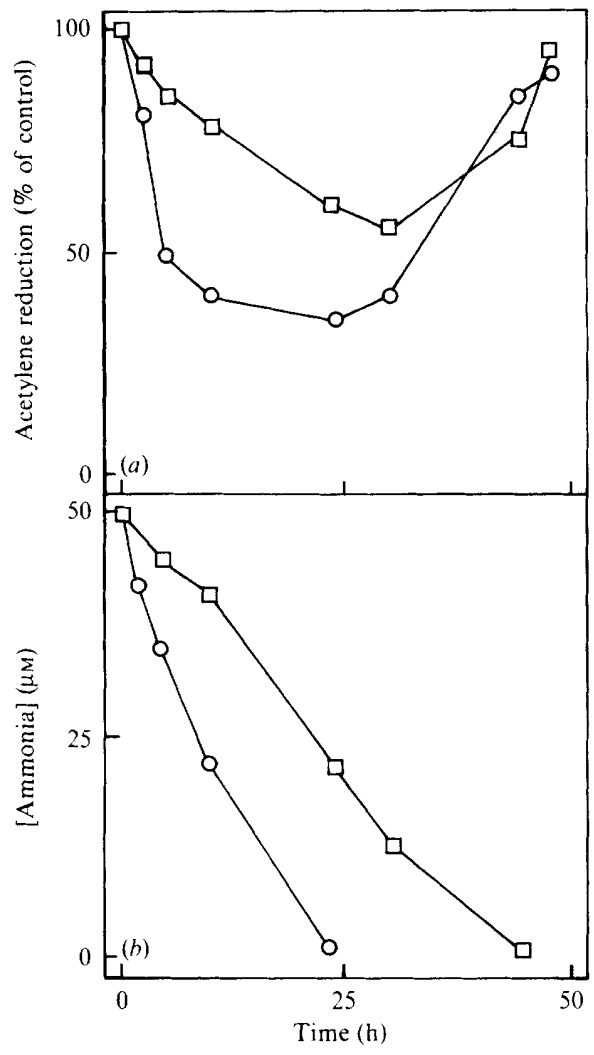

Fig. 7

Fig. 6. Effects of (a) $3 \mathrm{~mm}-\mathrm{NH}_{4} \mathrm{Cl}$ and (b) $3 \mathrm{mM}^{-} \mathrm{CH}_{3} \mathrm{NH}_{3} \mathrm{Cl}$, added at zero time, on nitrogenase activity of the parent strain $(O, \bullet)$ and mutant strain $4 \mathrm{~m} 3(\square, \boldsymbol{\square})$ grown in BG-11 $1_{0}$ medium at pH 7.0 and incubated in the same medium at $\mathrm{pH} 7.0(\mathrm{O}, \square)$ and $\mathrm{pH} 9 \cdot 0(\mathbf{0}, \mathbf{a})$. Nitrogenase activities at zero time were 6.8 and $6.9 \mathrm{nmol} \mathrm{C}_{2} \mathrm{H}_{2}$ reduced $\mathrm{h}^{-1}(\mu \mathrm{g} \mathrm{chl} a)^{-1}$ for the parent strain and strain $4 \mathrm{~m} 3$, respectively.

Fig. 7. Effects on nitrogenase activity of adding $50 \mu \mathrm{M}-\mathrm{NH}_{4} \mathrm{Cl}$, at zero time, to the parent strain (O) and mutant strain $4 \mathrm{~m} 3(\square)$ grown in BG-11 $1_{0}$ medium at $\mathrm{pH} 7.0$ and incubated in the same medium. (a) Nitrogenase activity; $(b) \mathrm{NH}_{4} \mathrm{Cl}$ concentration in the medium. Nitrogenase activities at zero time were 5.4 and $5.6 \mathrm{nmol} \mathrm{C}_{2} \mathrm{H}_{2}$ reduced $\mathrm{h}^{-1}(\mu \mathrm{g} \mathrm{chl} a)^{-1}$ for the parent strain and strain $4 \mathrm{~m} 3$, respectively.

Table 2. Effects of MSX on nitrogenase activity and ammonia liberation by the parent strain and mutant strain $4 \mathrm{~m} 3$

Cultures, grown in BG-11 $11_{0}$ medium at $\mathrm{pH} 7 \cdot 0$, were harvested by centrifugation, washed and resuspended in BG- $11_{0}$ medium supplemented with $10 \mu \mathrm{M}-\mathrm{MSX}$ and $20 \mathrm{mM}-\mathrm{NaNO}_{3}$, where indicated. After incubating at a photon fluence rate of $75 \mu \mathrm{mol} \mathrm{m} \mathbf{m}^{-2} \mathrm{~s}^{-1}$ for $24 \mathrm{~h}$, the acetylene reduction rates and concentrations of ammonia in the media were measured. All data are the mean \pm SE for at least five replicates. Figures in parentheses represent percentages of the respective control values. ND, Not detectable.

\begin{tabular}{|c|c|c|c|}
\hline Strain & $\begin{array}{l}\text { Additions } \\
\text { to medium }\end{array}$ & $\begin{array}{c}\text { Acetylene reduction } \\
{\left[\mathrm{nmol} \mathrm{h} \mathrm{h}^{-1}(\mu \mathrm{g} \operatorname{chl} a)^{-1}\right]}\end{array}$ & $\begin{array}{l}\text { Ammonia liber } \\
{[\mathrm{nmol}(\mu \mathrm{g} \mathrm{chl}}\end{array}$ \\
\hline Parent & $\begin{array}{l}\text { None } \\
\mathrm{NO}_{3}^{-} \\
\mathrm{MSX}^{-} \\
\mathrm{NO}_{3}, \mathrm{MSX}\end{array}$ & $\begin{array}{l}5.59 \pm 0.36(100) \\
4.31 \pm 0.30(77) \\
6.58 \pm 0.53(122) \\
5.13 \pm 0.21(95)\end{array}$ & $\begin{array}{c}\text { ND } \\
\text { ND } \\
27 \cdot 4 \pm 3 \cdot 9 \\
28 \cdot 1 \pm 2 \cdot 0\end{array}$ \\
\hline $4 \mathrm{~m} 3$ & $\begin{array}{l}\text { None } \\
\mathrm{NO}_{3} \\
\mathrm{MSX}^{-} \\
\mathrm{NO}_{3}, \mathrm{MSX}\end{array}$ & $\begin{array}{l}5.59 \pm 0.41(100) \\
3.19 \pm 0.25(57) \\
8.40 \pm 0.75(150) \\
7.05 \pm 0.84(126)\end{array}$ & $\begin{array}{c}\text { ND } \\
\text { ND } \\
37 \cdot 4 \pm 1 \cdot 9 \\
70 \cdot 8 \pm 3 \cdot 6\end{array}$ \\
\hline
\end{tabular}




\section{Extracellular liberation of ammonia}

Since it has been proposed that an $\mathrm{NH}_{4}^{+}$transport system is important for the retention of ammonia generated internally (Castorph \& Kleiner, 1984; Kleiner, 1985) by, for example, $\mathrm{N}_{2}-$ fixation, strain $4 \mathrm{~m} 3$ was tested for ammonia liberation. The data in Table 2 show that strain $4 \mathrm{~m} 3$, like the parent strain, only liberated ammonia extracellularly following treatment with MSX to inactivate GS (Stewart \& Rowell, 1975). However, nitrogenase activity was enhanced to a greater extent and the amount of ammonia liberated, over the $24 \mathrm{~h}$ experimental period, was greater for strain $4 \mathrm{~m} 3$ than for the parent strain. Additionally, ammonia liberation by strain $4 \mathrm{~m} 3$, following MSX treatment, was greater in the presence of nitrate.

\section{DISCUSSION}

The results obtained for the parent strain of Anabaena variabilis extend previous findings for $\mathrm{N}_{2}$-fixing cyanobacteria (Rai et al., 1984; Kerby et al., 1986a, 1987b) and for other cyanobacteria, particularly Anacystis nidulans (Boussiba et al., 1984a, $b$; Boussiba \& Gibson, 1985). The kinetics of uptake of methylamine and ammonia by strain $4 \mathrm{~m} 3$ suggest that it is defective in the active transport of $\mathrm{CH}_{3} \mathrm{NH}_{3}^{+}$and $\mathrm{NH}_{4}^{+}$.

The biphasic uptake of $\left[{ }^{14} \mathrm{C}\right]$ methylamine by cyanobacteria has been interpreted either as a rapid transport and a subsequent slower metabolism via GS (Rai et al., 1984), such that the ratelimiting step is metabolism, or as two active transport systems (Singh et al., 1983, 1985, 1987), the slower of which is inhibited by MSX. Data from this laboratory (Rai et al., 1984; Kerby et $a l ., 1986 a, 1987 a$; this paper), which are not consistent with the latter idea that the biphasic uptake represents two transport systems, indicate a clear correlation between GS biosynthetic activity and the rate of the second slower phase of uptake, either in mutant strains with reduced GS activity (ED81 and ED92) (Kerby et al., 1986b) or in the parent strain when GS has been inactivated by treatment with MSX. Our data show that the rate of the second phase of uptake of methylamine or ammonia is the same at $\mathrm{pH} 7.0$ as at $\mathrm{pH} 9.0$, indicating that this phase is not limited by the rate of transport, since both compounds can enter rapidly by passive diffusion and accumulate to a higher concentration at $\mathrm{pH} 9.0$. If active transport was rate-limiting, the rate of the second phase would presumably be greater at $\mathrm{pH} 9.0$ than at $\mathrm{pH} 7.0$. The reduction in the rate of the second phase of methylamine uptake by strain $4 \mathrm{~m} 3$ does not appear to be due to differences in the level or kinetic properties (our unpublished data) of GS, but the possibility that GS activity in vivo is limited by substrate a vailability or that there is a defect at a later step in the pathway of ammonia assimilation cannot be discounted.

Strain $4 \mathrm{~m} 3$ appears to have a methylamine-inducible $\mathrm{CH}_{3} \mathrm{NH}_{3}^{+}$transport system which is not induced by ammonia. Metabolism of $\left[{ }^{14} \mathrm{C}\right]$ methylamine by strain $4 \mathrm{~m} 3$ is limited to the synthesis and accumulation of $\gamma$-methylglutamine, as we have previously shown for the parent strain (Rai et al., 1984; Kerby et al., 1986a). Resistance of strain $4 \mathrm{~m} 3$ to methylamine cannot, therefore, simply be ascribed to an inability to synthesize $\gamma$-methylglutamine as in some mutant strains of Escherichia coli (Servin-Gonzalez et al., 1987).

Mutant strain $4 \mathrm{~m} 3$ did not liberate ammonia extracellularly unless GS was inactivated by treatment with MSX, in contrast with findings for an $\mathrm{NH}_{4}^{+}$-transport-deficient mutant of Klebsiella pneumoniae (Castorph \& Kleiner, 1984) but in agreement with findings for an $\mathrm{NH}_{4}^{+-}$ transport-deficient mutant of Chlamydomonas reinhardtii (Franco et al., 1987), suggesting that an active $\mathrm{NH}_{4}^{+}$-transport system is not essential for the retention of internally-generated ammonia in this cyanobacterium. This is clearly the case whether ammonia is derived via $\mathrm{N}_{2}$ fixation in heterocysts or via processes such as $\mathrm{NO}_{3}^{-}$reduction (Rai \& Bergman, 1986) or photorespiratory nitrogen cycling (Bergman, 1984) in vegetative cells. However, the liberation of ammonia by strain $4 \mathrm{~m} 3$, treated with MSX, is more extensive than that by the parent strain, particularly in the presence of nitrate. Such increased liberation of ammonia by strain $4 \mathrm{~m} 3$ may be due to the increased nitrogenase activity (Table 2) and, possibly, to an increased nitrate reductase activity. However, the possibilities that it is due to the deficiency in $\mathrm{NH}_{4}^{+}$transport, to an increased uptake of MSX or to an alteration of GS, making it more susceptible to inactivation by MSX, cannot be discounted. 
The finding that nitrogenase activity in strain $4 \mathrm{~m} 3$ is less sensitive to inhibition by exogenous ammonia at $\mathrm{pH} 7.0$ is, presumably, due to the reduced ability, at this $\mathrm{pH}$, to accumulate intracellularly the ammonia and/or a product of its assimilation which are involved in the regulation of nitrogenase synthesis. The inhibitory effect of ammonia on nitrogenase activity at $\mathrm{pH} \mathrm{7.0} \mathrm{and} \mathrm{pH} 9.0$ is prevented by MSX, suggesting the involvement of a product of ammonia assimilation (Kerby et al., 1987a). In contrast, the rapid decrease in nitrogenase activity on adding methylamine at $\mathrm{pH} 9.0$ is only partly prevented by MSX treatment and is probably mainly due to uncoupling (Kerby et al., 1987a). Further studies on the ammonia regulation of nitrogenase activity in strain $4 \mathrm{~m} 3$ and on the interrelationships between $\mathrm{NH}_{4}^{+}$transport and assimilation in $A$. variabilis are in progress.

We thank the Science and Engineering Research Council and the Agricultural and Food Research Council for financial support, Miss W. Wallace for expert technical assistance and Miss A. Alexander for critical reading of the manuscript.

\section{REFERENCES}

AleF, K. \& KleineR, D. (1982). Evidence for an ammonium transport system in the $\mathrm{N}_{2}$-fixing phototrophic bacterium Rhodospirillum rubrum. Archives of Microbiology 132, 79-81.

BERGMAN, B. (1984). Photorespiratory ammonium release by the cyanobacterium Anabaena cylindrica in the presence of methionine sulphoximine. Archives of Microbiology 137, 21-25.

Boussiba, S. \& Gibson, J. (1985). The role of glutamine synthetase activity in ammonium and methylammonium transport in Anacystis nidulans R-2. FEBS Letters 180, 13-16.

Boussiba, S., Dilling, W. \& Gibson, J. (1984a). Methylammonium transport in Anacystis nidulans R-2. Journal of Bacteriology 160, 204-210.

Boussiba, S., Resch, C. M. \& Gibson, J. (1984b) Ammonia uptake and retention in some cyanobacteria. Archives of Microbiology 138, 287-292.

BRADFORD, M. M. (1976). A rapid and sensitive method for the quantitation of microgram quantities of protein utilizing the principles of protein-dye binding. Analytical Biochemistry 72, 248-254.

CastorPH, H. \& Kleiner, D. (1984). Some properties of a Klebsiella pneumoniae ammonium transport negative mutant $\left(\mathrm{Amt}^{-}\right)$. Archives of Microbiology 139, 245-247.

EaDY, R. R., KaHN, D. \& Buchanan-Wollaston, V. (1982). The molecular enzymology of nitrogen fixation. Israel Journal of Botany 31, 45-60.

Franco, A. R., Cardenas, J. \& Fernandez, E. (1987). A mutant of Chlamydomonas reinhardtii altered in the transport of ammonium and methylammonium. Molecular and General Genetics 206, 414-418.

HaWkesford, M. J., Rowell, P. \& Stewart, W. D. P. (1983). Energy transduction in cyanobacteria. In Photosynthetic Prokaryotes: Cell Differentiation and Function, pp. 199-218. Edited by G. C. Papageorgiou \& L. Packer. New York: Elsevier.

Helber, J., Johnson, T. R., Yarbrough, L. R. \& HIRSCHBERG, R. (1988). Effect of nitrogenous compounds on nitrogenase gene expression in anaerobic cultures of Anabaena variabilis. Journal of Bacteriology 170, 558-563.

Hien, N. T., Kerby, N. W., Machray, G. C., Rowell, P. \& Stewart, W. D. P. (1988). Expression of glutamine synthetase in mutant strains of the cyanobacterium Anabaena variabilis which liberate ammonia. FEMS Microbiology Letters 56, 337-342.

Kerby, N. W., Rowell, P. \& Stewart, W. D. P. $(1986 a)$. The uptake and metabolism of methylamine by $\mathrm{N}_{2}$-fixing cyanobacteria. Archives of Microbiology 143, 353-358.

Kerby, N. W., Musgrave, S. C., Rowell, P., Shestakov, S. V. \& Stewart, W. D. P. (1986 b). Photoproduction of ammonium by immobilised mutant strains of Anabaena variabilis. Applied Microbiology and Biotechnology 24, 42-46.

Kerby, N. W., Rowell, P. \& Stewart, W. D. P. (1987a). Cyanobacterial ammonium transport, ammonium assimilation and nitrogenase regulation. New Zealand Journal of Marine and Freshwater Research 21, 447-455.

Kerby, N. W., Niven, G. W., Rowell, P. \& Stewart, W. D. P. $(1987 b)$. Photoproduction of amino acids by mutant strains of $\mathrm{N}_{2}$-fixing cyanobacteria. Applied Microbiology and Biotechnology 25, 547-552.

KLEINER, D. (1985). Energy expenditure for cyclic retention of $\mathrm{NH}_{3} / \mathrm{NH}_{4}^{+}$during $\mathrm{N}_{2}$ fixation by Klebsiella pneumoniae. FEBS Letters 187, 237-239.

Mackinney, G. (1941). Absorption of light by chlorophyll solutions. Journal of Biological Chemistry 140, 315-322.

MurRy, M. A. \& Beneminn, J. R. (1979). Nitrogenase regulation in Anabaena cylindrica. Plant and Cell Physiology 20, 1391-1401.

OhmoRi, M., OhmoRi, K. \& Strotmann, H. (1977). Inhibition of nitrate uptake by ammonia in a bluegreen alga Anabaena cylindrica. Archives of Microbiology 114, 225-229.

Polukhina, L. E., Sakhurieva, G. N. \& Shestakov, S. V. (1982). Ethylenediamine resistant Anabaena variabilis mutants with derepressed nitrogen fixing system. Microbiology 51, 90-95.

RAI, A. N. \& BERGMAN, B. (1986). Modification of $\mathrm{NO}_{3}^{-}$metabolism in heterocysts of the $\mathrm{N}_{2}$-fixing cyanobacterium Anabaena 7120 (ATCC 27893). FEMS Microbiology Letters 36, 133-137.

Rai, A. N., Rowell, P. \& Stewart, W. D. P. (1984). Evidence for an ammonium transport system in free living and symbiotic cyanobacteria. Archives of Microbiology 137, 241-246. 
Ramos, J. L., Madueno, F. \& Guerrero, M. (1985). Regulation of nitrogenase levels in Anabaena sp. ATCC 33047 and other filamentous cyanobacteria. Archives of Microbiology 141, 105-111.

Reed, R. H., Kerby, N. W. \& Stewart, W. D. P. (1987). Particle size analysis of unicells formed by mild sonication of filaments of the blue-green alga Anabaena variabilis. Phycologia 26, 391-393.

Reich, S., Almon, H. \& Boger, P. (1986). Short-term effect of ammonia on nitrogenase activity of Anabaena variabilis (ATCC 29413). FEMS Microbiology Letters 34, 53-56.

RIPPKa, R., DeRUelles, J., WATERbURY, J. B., Herdman, M. \& StanieR, R. Y. (1979). Generic assignments, strain histories and properties of pure cultures of cyanobacteria. Journal of General Microbiology 111, 1-61.

Rowell, P., Enticott, S. \& Stewart, W. D. P. (1977). Glutamine synthetase and nitrogenase activity in the blue-green alga Anabaena cylindrica. New Phytologist 79, 41-54.

Servin-GonZalez, L., Ortiz, M., Gonzalez, A. \& BASTARRACHEA, F. (1987). gln $A$ mutations conferring resistance to methylammonium in Escherichia coli K12. Journal of General Microbiology 133, 16311639.

Singh, D. T., RaI, A. N. \& Singh, H. N. (1985). Methylammonium (ammonium) uptake in a glutamine auxotroph of the cyanobacterium Anabaena cycadae. FEBS Letters 186, 51-53.

Singh, D. T., Ghosh, R. \& Singh, H. N. (1987).
Physiological characterisation of the ammonium transport system in the free-living diazotrophic cyanobacterium Anabaena cycadae. Journal of Plant Physiology 127, 231-239.

SINGH, H. N., RaI, U. N., RAO, V. V. \& BAGCHI, S. N. (1983). Evidence for ammonia as an inhibitor of heterocyst and nitrogenase formation in the cyanobacterium Anabaena cycadae. Biochemical and Biophysical Research Communications 111, 180-187.

SoloRZANO, L. (1969). Determination of ammonia in natural waters by the phenolhypochlorite method. Limnology and Oceanography 14, 799-801.

Stewart, W. D. P. \& RowelL, P. (1975). Effects of Lmethionine-DL-sulphoximine on the assimilation of newly fixed $\mathrm{NH}_{3}$, acetylene reduction and heterocyst production in Anabaena cylindrica. Biochemical and Biophysical Research Communications 65, 846-857.

Stewart, W. D. P., Fitzgerald, G. P. \& Burris, R. H. (1967). In situ studies on $\mathrm{N}_{2}$-fixation using the acetylene reduction technique. Proceedings of the National Academy of Sciences of the United States of America 58, 2071-2078.

Stewart, W. D. P., Rowell, P., Cossar, J. D. \& Kerby, N. W. (1985). Physiological studies on $\mathrm{N}_{2}$ fixing cyanobacteria. In Nitrogen Fixation and $\mathrm{CO}_{2}$ Metabolism, pp. 269-279. Edited by P. W. Ludden \& J. E. Burris. New York: Elsevier.

Turpin, D. H., Edie, S. A. \& CANvin, D. T. (1984). In vivo nitrogenase regulation by ammonium and the effect of MSX on ammonium transport in Anabaena flos-aquae. Plant Physiology 74, 701-704. 